\title{
Periprocedural management of acute ischemic stroke patients undergoing endovascular therapy
}

Chethan P. Venkatasubba Rao, MD

Jose I. Suarez, MD

Correspondence \& reprint requests to Dr. Suarez: jisuarez@bcm.edu

Neurology ${ }^{\circledR}$ 2012;79 (Suppl 1):S165-S166
The physiologic derangements in acute stroke victims are dynamic. As noted extensively in the literature, there is mounting evidence to support that patients with large strokes, measured clinically through NIH Stroke Scale (NIHSS) ${ }^{1}$ or by radiologic methods, ${ }^{2}$ have increased mortality and are severely ill. Endovascular treatment of ischemic strokes inherently imposes a host of physiologic changes. Changes in cerebral perfusion and cerebral autoregulation need adequate hemodynamic support. Unintentionally induced changes during general anesthesia and potential hyperperfusion injury after revascularization may cause adverse outcomes. The loss of blood-brain barrier integrity poses additional challenges to antiplatelet and anticoagulant regimen. The primary goal of critical care management is to cater to the constantly changing cerebral perfusion in the background of loss of cerebral autoregulation. The practice remains varied in the community, administered by intensivists, anesthesiologists, and sometimes neurointerventional physicians. The individual and collective merits and demerits of current practice are unknown and have to be evaluated systematically. Admittedly, there exists no Class Ia evidence, and it is difficult and sometimes impossible to obtain evidence to support the use of a definitive management. The Society of Vascular \& Interventional Neurology (SVIN) roundtable proceeding has systematically identified the key areas of care that have a potential to improve outcomes. This is an important step in a relatively young field where many questions are yet to be answered. For instance, blood pressure management before, during, and after endovascular procedures has not been formally tested. In our view, the following 5 articles will serve as an educational tool for readers about the state of current practice.

The first article discusses general anesthesia in patients undergoing endovascular reperfusion therapy. Administering anesthesia can compromise perfusion pressure and clinical examination as a tradeoff for patient cooperation. Even though a randomized trial comparing general anesthesia to conscious sedation is impractical, a systematic study needs to be done to identify the factors that can improve outcomes for patients.

The second article provides a comprehensive summary of the utility of various antiplatelet agents and anticoagulants in the setting of endovascular intervention. Deranged integrity of the blood-brain barrier with the loss of cerebral autoregulation poses a formidable threat for hemorrhagic transformation. The authors report the historical rates of symptomatic intraparenchymal hemorrhages in patients treated with various agents. This sets up a platform for clinical trials to address the efficacy and safety of many of the agents. The use of antiplatelet agents can become even more challenging with the deployment of intracranial stents, ${ }^{3}$ balancing the risk of reocclusion against the risk of causing intracranial hemorrhage. In addition, if a patient were to be a candidate for hemicraniectomy, ${ }^{4}$ these agents could potentially increase the perioperative morbidity and mortality.

The third article presents a meticulous overview of the management of a case in the periprocedural period. Many aspects such as imaging modalities, critical care service, and pharmacotherapy choices are either operator dependent or institutionally regulated. However, the framework of the operations should be constant and consistent. In addition, it is always advisable to establish a conversation with the patient proxy in time to prevent any delay in revascularization. One important point that is missing from the discussion is that as a routine practice, enrollment in available studies should always be encouraged. 5

"Primum non nocere" is undeniably the dictum that all physicians abide by. ${ }^{6}$ Nevertheless, complications do happen from multiple sources when navigating through the already diseased intracranial circulation. The fourth article comprises an extensive review of the systemic, procedural, and pharmacologically mediated complications in patients treated with endovascular recanalization therapy for ischemic stroke. This article can be used as a guide to discuss the complications while communicating to the next of kin of the diseased. 
In the last article, the reader can find an exhaustive review of literature on the management of blood pressure in post-endovascular treatment patients. The authors detail the current recommendations from the American Stroke Association, based on pathophysiology, and caution the reader to the don'ts in managing blood pressure. The main point to consider here is whether cerebral perfusion changes with revascularization and what hemodynamic changes need to be instituted to prevent hyperperfusion. Is there a hyperperfusion? Do induced hemodynamic changes improve outcome? Only trials can test these hypotheses.

The SVIN roundtable meeting proceeding has served 2 purposes. It has identified pitfalls in the current practice and opened an opportunity to address them scientifically. There are and will be challenges, scanty evidence that require logical deductions at every clinical juncture. It is only through a consorted systematized approach and trials that we can engage them successfully.

\section{AUTHOR CONTRIBUTIONS}

Dr. Venkatasubba Rao: drafting/revising the manuscript. Dr. Suarez: drafting/revising the manuscript, study concept or design, analysis or in terpretation of data.

\section{DISCLOSURE}

Dr. Venkatasubba Rao has served on the Editorial Board for Brain Disorders and Therapy. Dr. Suarez serves on the Editorial Board of Stroke,
Neurocritical Care, and Journal of Interventional Neurology; serves on the speakers bureaus of Boehringer-Ingelheim and Bristol-MyersSquibb/Sanofi; and has received research support from NINDS. Go to Neurology.org for full disclosures.

Received July 25, 2011. Accepted in final form October 17, 2011.

\section{REFERENCES}

1. Frankel MR, Morgenstern LB, Kwiatkowski T, et al. Predicting prognosis after stroke: a placebo group analysis from the National Institute of Neurological Disorders and Stroke rt-PA Stroke Trial. Neurology 2000;55: 952-959.

2. Barber PA, Demchuk AM, Zhang J, Buchan AM. Validity and reliability of a quantitative computed tomography score in predicting outcome of hyperacute stroke before thrombolytic therapy: ASPECTS Study Group: Alberta Stroke Programme Early CT Score. Lancet 2000;355: $1670-1674$.

3. Linfante I, Samaniego EA, Geisbusch P, Dabus G. Selfexpandable stents in the treatment of acute ischemic stroke refractory to current thrombectomy devices. Stroke 2011; 42:2636-2638.

4. Vahedi K, Hofmeijer J, Juettler E, et al. Early decompressive surgery in malignant infarction of the middle cerebral artery: a pooled analysis of three randomised controlled trials. Lancet Neurol 2007;6:215-222.

5. Chimowitz MI, Lynn MJ, Derdeyn CP, et al. Stenting versus aggressive medical therapy for intracranial arterial stenosis. N Engl J Med 2011;365:993-1003.

6. Aring CD. Primum non nocere. Arch Intern Med 1965; 115:345-350. 


\section{Neurology}

\section{Periprocedural management of acute ischemic stroke patients undergoing endovascular therapy \\ Chethan P. Venkatasubba Rao and Jose I. Suarez Neurology 2012;79;S165-S166 \\ DOI 10.1212/WNL.0b013e318269598f}

This information is current as of September 24, 2012

\section{Updated Information \&} Services

References

Subspecialty Collections

Permissions \& Licensing

Reprints including high resolution figures, can be found at: http://n.neurology.org/content/79/13_Supplement_1/S165.full

This article cites 6 articles, 2 of which you can access for free at: http://n.neurology.org/content/79/13_Supplement_1/S165.full\#ref-list1

This article, along with others on similar topics, appears in the following collection(s):

\section{All Cerebrovascular disease/Stroke}

http://n.neurology.org/cgi/collection/all_cerebrovascular_disease_strok e

All Medical/Systemic disease

http://n.neurology.org/cgi/collection/all_medical_systemic_disease

Information about reproducing this article in parts (figures,tables) or in its entirety can be found online at:

http://www.neurology.org/about/about_the_journal\#permissions

Information about ordering reprints can be found online:

http://n.neurology.org/subscribers/advertise

Neurology ${ }^{\circledR}$ is the official journal of the American Academy of Neurology. Published continuously since 1951, it is now a weekly with 48 issues per year. Copyright Copyright $@ 2012$ by AAN Enterprises, Inc.. All rights reserved. Print ISSN: 0028-3878. Online ISSN: 1526-632X.

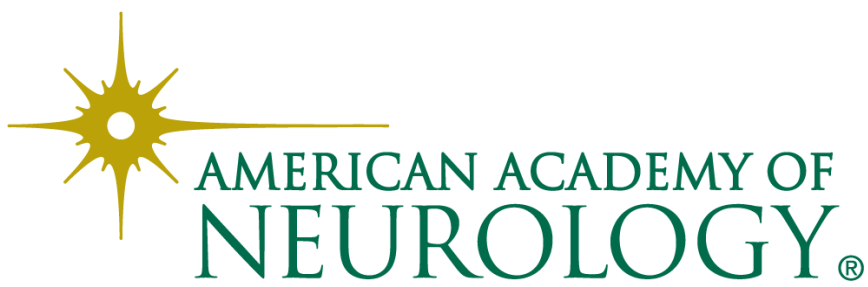

